\title{
Influences of the Developments and Issues Related to the Sustainability of Regionalism in Gojal, Northern Areas of Pakistan
}

\section{パキスタン北部地域ゴジャール地区における開発の影響と地域性の持続に向けた課題}

\section{Yasuhiro OCHIAI* \\ 落合 康浩*}

Key words : traditional lifestyle, potato cultivation, tourism, self-directed development, Northern Areas of Pakistan

キーワード : 伝統的生活様式, ジャガイモ栽培, 観光業, 内発的発展, パキスタン北部地域

\section{要旨}

本稿は, パキスタン北部地域ゴジャール地区の開発にともなう農牧業形態の変化や観光化の進展, 住民の生活の実態 について分析し，そこに存在する問題点を整理しながらこの地区の持続的発展に向けての課題について考察するものであ る。

ゴジャール地区はカラコラムハイウェイ $(\mathrm{KKH})$ の開通㧍よび外国人への開放と, アガ・ハーン財団などNGOによる開 発事業の推進により, 物流の増大や観光客の流入, 農業構造の改善, 児童教育の普及が促進された。中でもパスー村は地 の利を得て開発の進展が著しく, 農業は商品作物であるジャガイモの栽培に特化したものになり, 観光関連産業が村内に 成長した。村人の現金収入は拡大したが, 支出もまた増大し, 新たな就業機会や収入増加の道を模索する必要も生じてい る。

こうした状況は，観光業を推進する上で不可欠な地域固有の貴重な資源，すなわち地域の個性でもある伝統的な生活 様式を失うことにもなりかねない。それを回避するには，地域をよく理解する地元の人々自らが，適正な開発理念を考案 し，独自の手法による開発を推進する必要がある。そしてそのために重要なのが, 地域住民の組織力の強化である。住民 の自主的な組織によって, 新たな生産活動の成長を促し, 一方で伝統的な技術や文化を継承していく支援を続けながら， それらを村の経済発展に活用する方法を見出していくことを検討しなければならない。各々の住民，さらには各村々の役 割についても配慮し，分業体制，もしくは相互補完システムを構築することも重要である。何よりもゴジャール地区は， 教育水準の高い有為な人材に恵まれており，その力を結集することで，地域の組織化，そして持続的な開発を実現するこ とは十分に可能であると考えられる。

\section{I . Preface}

The Northern Areas is a region of federally administrated districts located in the northernmost area of Pakistan, and it is bordered by Afghanistan and the People's Republic of China to the north and Jammu and Kashmir, India to the southeast (Fig. 1). The Northern Areas lies to the north of the westernmost extremes of the Himalaya Range and is a mountainous zone encompassing portions of the Karakoram, Hindu Kush and Pamir Ranges. The basins of the river valleys that are given shape by the Indus River, which flows through the region's central area, as well as its tributaries, the Gilgit and Hunza Rivers, are characterized by arid climates. For instance, the annual precipitation in Gilgit, a city in the centre of the region, is approximately $150 \mathrm{~mm}$.

The Northern Areas of Pakistan is a region in which multiple minorities are distributed in a complex manner. Weeks (1984), for instance, describes these people in his introduction to the Islamic

${ }^{*}$ College of Humanities and Sciences, Nihon University, Japan/日本大学文理学部 


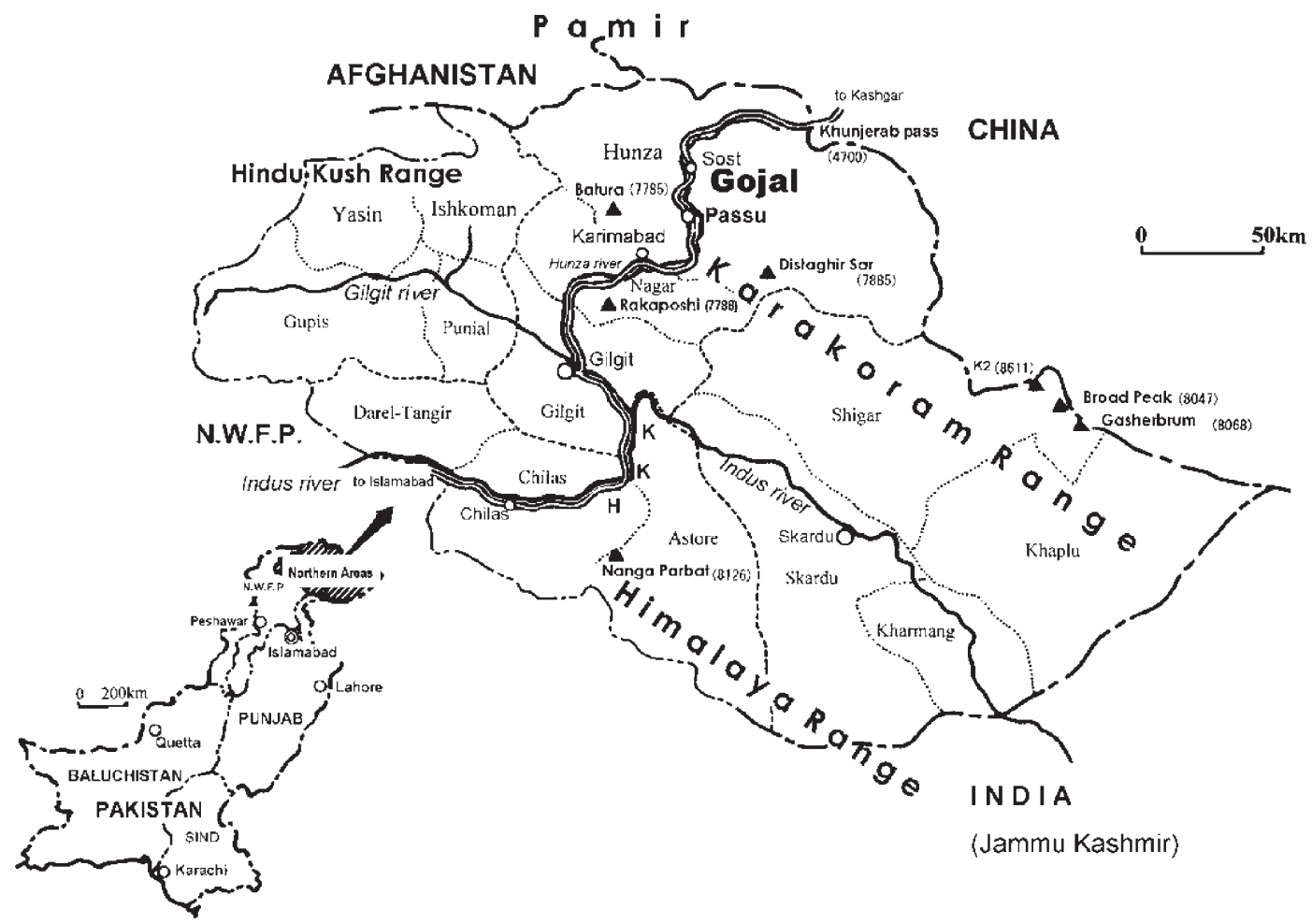

Fig. 1. The Northern Areas of Pakistan.

peoples of the world, noting that their subsistence is dependent upon stock farming and irrigated agriculture. In his travel journal, Namai (1982) describes the agricultural practices of Hunza, which is located in the northernmost portion of the Northern Areas, and Hiroshima (1987) writes of the local religious and agricultural practices. The central area of Hunza is also known for its mountainous sightseeing, and as it is the tourist base in the northern region, the social changes accompanying its development and continuing transformation into a tourist destination are prominent. Kreutzmann (1993), for instance, analyses this process of socioeconomic transformation and examines its main causes. Furthermore, Nejima (2002) analyses and examines the present state and influences of the community development being conducted by an NGO belonging to the Ismaili sect of Islam, to which the people of Hunza belong. According to this research, even in Hunza, which is located in a remote mountainous zone and whose natural/agricultural features have experienced little change, a drastic transformation is occurring in the region's economic makeup and social systems.

The upper Hunza region, also known as Gojal, lies within Hunza along the upper reaches of the Hunza River, and its ethnic makeup differs from that of the central area. The unique language, indigenous culture and lifestyle maintained by the people in Gojal are described in, for example, Sakai (1989), and considerable changes have begun to appear in recent years in these aspects as well.

A group from Nihon University started an exchange project with the inhabitants of the area in 1988, the details of which are given in Yamauchi (1989). Furthermore, geography researchers from Nihon University continue to conduct research on the natural and human environment of the region. For instance, see reports based on the research on the natural environment by Waragai (1995, 1996, 1997, 1999, 2001, 2008), on irrigated agriculture by Mizushima (1990, 2006, 2008) and on changes in 
lifestyle and the region's transformation into a tourist destination by Ochiai (1999, 2000, 2001, 2003, 2008) and Ochiai and Mizushima (2004). These reports shed light on Gojal's environmental and social characteristics as well as the mechanisms that have created change in these respects, and also offer a glimpse of the various problems which are slowly coming to the fore in the region.

The present report, then, deals with the regional transformation process accompanying the development and local development policies in Gojal by analysing the influence exerted upon the lifestyle of the people due to changes in the agricultural practices and the region's continuing transformation into a tourist destination, which spawns associated problems. Moreover, this report considers how sustainable development can be achieved in the area.

\section{Traditional ways of life in Gojal}

Gojal lies in the very innermost region of Hunza in the Northern Areas of Pakistan. The region extends from Shishkat village in the south to the Chinese border in the north, encompassing portions of the Karakoram and Pamir Ranges, and it is characterized by the presence of Distaghir Sar (7,785 m) as well as a number of other 7,000 m peaks and multiple glaciers (Fig. 2). River valleys such as the Hunza, along which human settlements exist, are located approximately 2,400-3,000 m a.s.l., are markedly dry and are subject to extreme climate conditions, with daytime temperatures exceeding $30^{\circ} \mathrm{C}$ during summer and temperatures falling below $-10^{\circ} \mathrm{C}$ in winter.

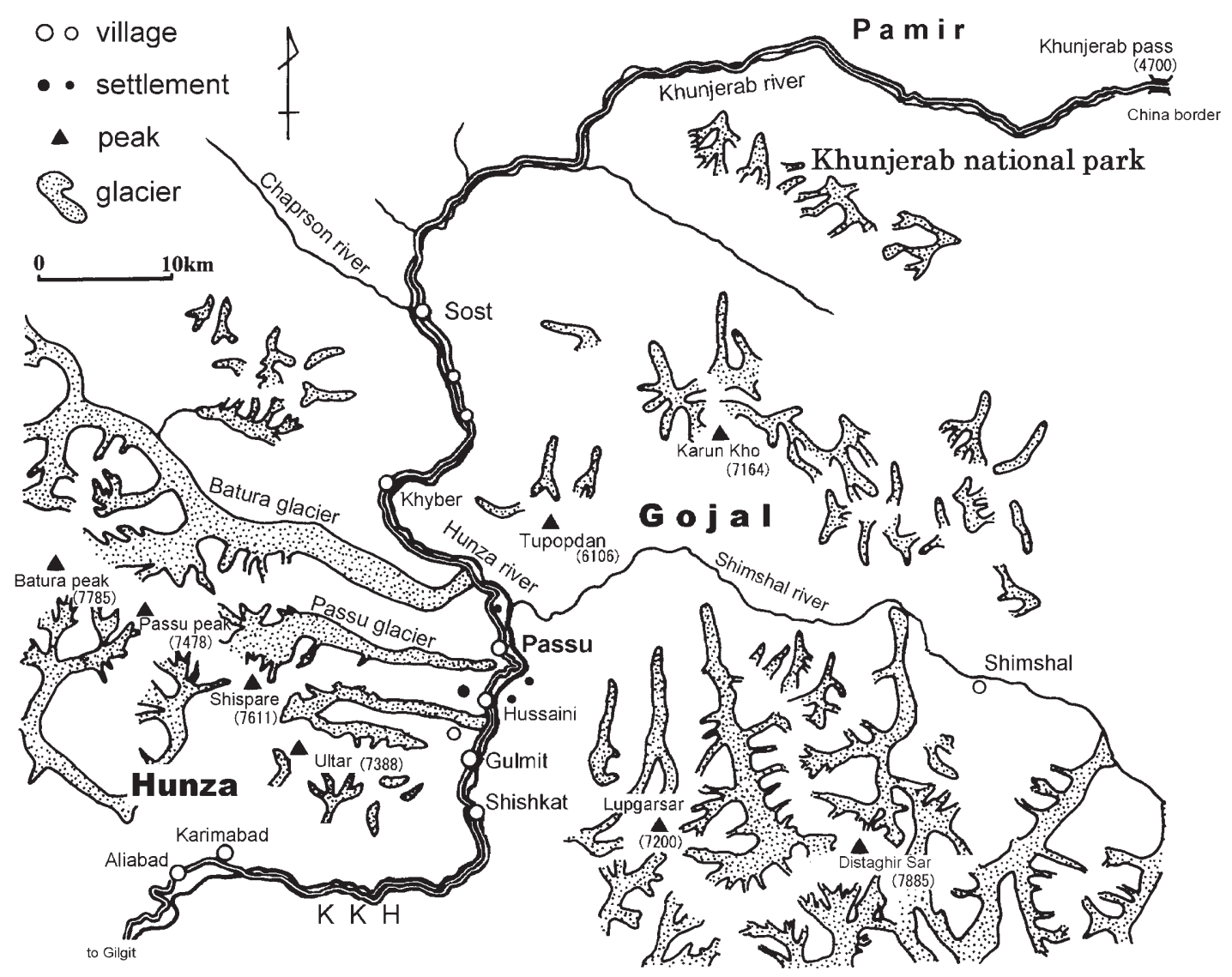

Fig. 2. Gojal area. 
The population of the region is approximately $17,000(2005)^{1)}$, approximately $80 \%$ of which belongs to the Wakhi group. The Wakhi are the descendents of the Afghans who expanded their territory outward; this ethnic group is found in the four countries of Afghanistan, Tajikistan, China and Pakistan (Fig. 3). Their native language is Wakhi, which traditionally has no written characters, belongs to the Iranian language group of Indo-European languages and resembles Tajik. With respect to religion, the Wakhi belong to the Khwaja sub-sect of the Ismaili Muslims, and they revere Aga Khan IV as their imam.

The traditional Wakhi lifestyle depends upon

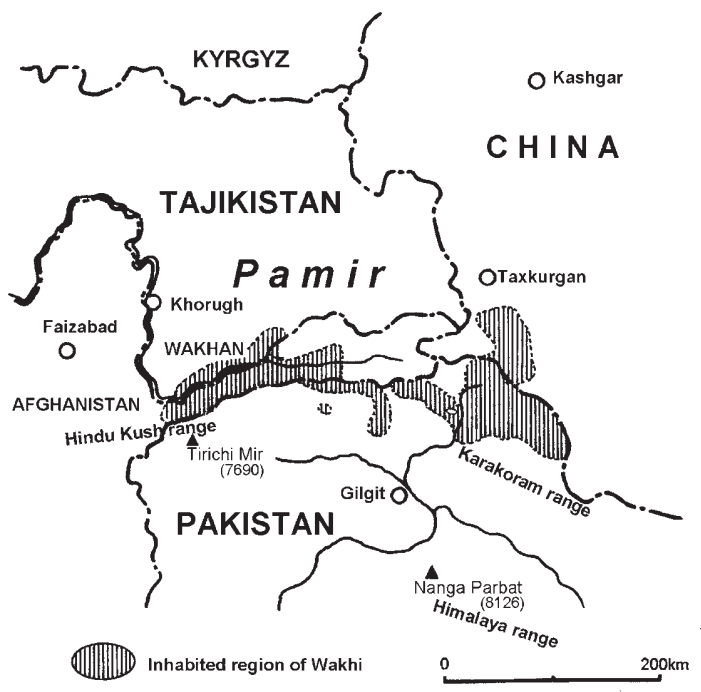

Fig. 3. Inhabited region of Wakhi. irrigated agriculture and stock farming. Irrigated agriculture allows the Wakhi to cultivate mainly subsistence upland field crops such as wheat, barley and peas, as well as fruit trees such as apricot and apple, irrigating the cultivated land by directing nearby spring water and runoff from the glacier at the rear of the village through canals (Mizushima, 1990). The cultivated grains are processed through milling and turned into staples such as capati, while the fruits are dried in the sun to be used in preserved form.

Livestock such as yaks, goats and sheep are raised through transhumance agriculture. Goats and sheep, for instance, are raised during the winter months, that is, October through April, near the home village; however, during other seasons, they are dispersed in a number of different high-altitude, elevated pastures which are utilized in turn as the seasons change (Ochiai, 1999). The manufacture of dairy products from the milk of these livestock, such as ghee and kurut, has traditionally been the task of the female.

These forms of agriculture and the accompanying rituals as well as a dietary culture which includes various means of preparing the produced ingredients form the unique lifestyle traditionally inherited by the Wakhi. However, in the villages of Gojal, this lifestyle is undergoing great change. The expanded movement of people and goods brought about by the construction of highways and the opening of the area to foreigners, as well as external factors such as growth in regional development based on the involvement of NGOs, are having pronounced effects. I will now offer a detailed description of the present state of the development which has contributed greatly to the changes in Gojal.

\section{The present state of development in Gojal}

Firstly, the opening of the Karakoram Highway (KKH) has contributed significantly to the development in Gojal. The KKH was designed to provide a secure route with the centre of Pakistan for the flow of goods, and thus, foster development and economic growth in the Northern Areas of Pakistan. When the construction of the KKH began in the 1960s, Pakistan's relations with India and the Soviet Union were strained; thus, it was of strategic importance as a direct transportation link with China, with whom relations were friendly. Needless to say, construction was carried out 
with strong support from China, and in 1978, the link was established all the way from Islamabad to Kashgar. In 1986, the route was opened to those of non-Pakistani and Chinese nationality, and a number of foreign tourists began visiting $\mathrm{Gojal}^{2)}$. Moreover, this route enabled travellers to reach Gojal from Gilgit in approximate four to five hours, and the increased convenience in transportation caused the penetration of a commodity economy in the area.

The participation of the Aga Khan Foundation (AKF) in the regional development has also had a great impact. This foundation, which is chaired by Aga Khan IV, the Ismaili imam, established the Aga Khan Rural Support Programme (AKRSP) in Gilgit in 1982 to promote development in the villages of Pakistan's northern region. Its projects are centred upon money circulation, the establishment of infrastructure, agricultural guidance, foresting projects and human development projects. To efficiently develop these projects, the AKRSP has established Village Organizations (VO) and Women's Organizations (WO) (AKRSP, 1988). Finance is the organization's main activity, and the capital loaned to citizens comes from deposits collected from members and loans from AKRSP itself. Citizens receive loans from the project, acquiring capital which is used to expand agricultural operations. In addition, the VO and WO introduce not only new crops but farm machines such as tractors, threshing machines, etc., for shared use, thereby carrying out structural improvements in agriculture.

Through the Aga Khan Education Service (AKES), Aga Khan IV has also established diamond jubilee (DJ) schools ${ }^{3)}$ in the villages of the northern region, implementing a substantial programme which focuses on English education and the teacher training system, and thus, contributes to the dissemination of high-quality education. In Gojal, for instance, a DJ school was opened in Passu (Pasu) village in 1969, and as of 2007, nearly 100\% of the school age village children were attending school.

\section{Changes in living conditions in Passu village}

\section{Continuing development}

Passu village is located somewhat south of the central area of Gojal at an elevation of approximately $2,500 \mathrm{~m}$ and contains 112 households with a population of $872(2006)^{4)}$ (Photo 1). The central settlement lies above the alluvial fan formed at the point where runoff from the tip of the Passu glacier converges with the Hunza River, and the KKH passes through the settlement. Since 1987, the electricity has been provided by a power plant in a neighbouring village, and while the supply is unstable, it can be used all year round. The

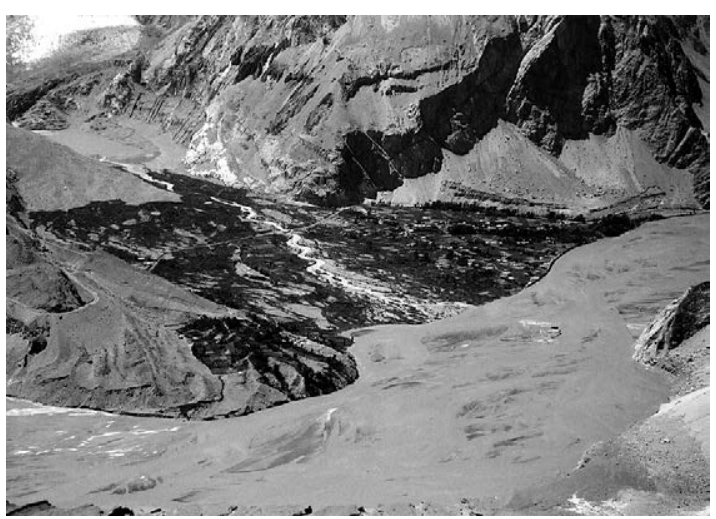

Photo 1. View of Passu village (Photo: July 2000). waterworks was constructed in 1992 using the underflow from the Passu glacier, and it supplies water to every house. In 2004, it became possible to use telephones inside the houses in the village, making this one of the most developmentally advanced villages in Gojal in terms of the establishment of infrastructure.

In the agricultural industry, the cultivation of potatoes is increasing. The potato is a crop which is suited to the area's land and climate conditions, and as it became possible to ship crops to markets 
in urban areas via the $\mathrm{KKH}$, highquality varieties were introduced in the mid-1980s as cash crops. Potatoes fetched high prices at market; therefore, the villages of Gojal, including Passu village, recognized that the expansion of the cultivation of the potato would effectively produce cash income, and replaced the subsistence crops such as grains. As with other villages in the area, the proportion of space used to cultivate potatoes in Passu village was overwhelmingly large, and in the central settlement, $80 \%$ of the arable land was devoted entirely to this purpose (Fig. 4). In the case of apples as well, delicious varieties with high monetary value were eventually added to the existing varieties, cultivated, and shipped to other locales. Thus, we may observe significant changes in agriculture in general with regard to the cultivated crops and their varieties.

Passu village is also a popular tourist attraction. A number of 7,000 $\mathrm{m}$ peaks stand high behind the village ${ }^{5)}$, and the Passu and Batura glaciers, which flow down these peaks, lie just next to the village (Photo 2). The grazing land of Passu village lies along the sloping left side of the Batura glacier, and the village is surrounded by mountainous scenery which is prized for its uncommon beauty. Furthermore, the village is located at the entrance to Shimshal valley, which is known for its magnificent scenery. Consequently, ever since the KKH was opened to foreigners, the number of visitors

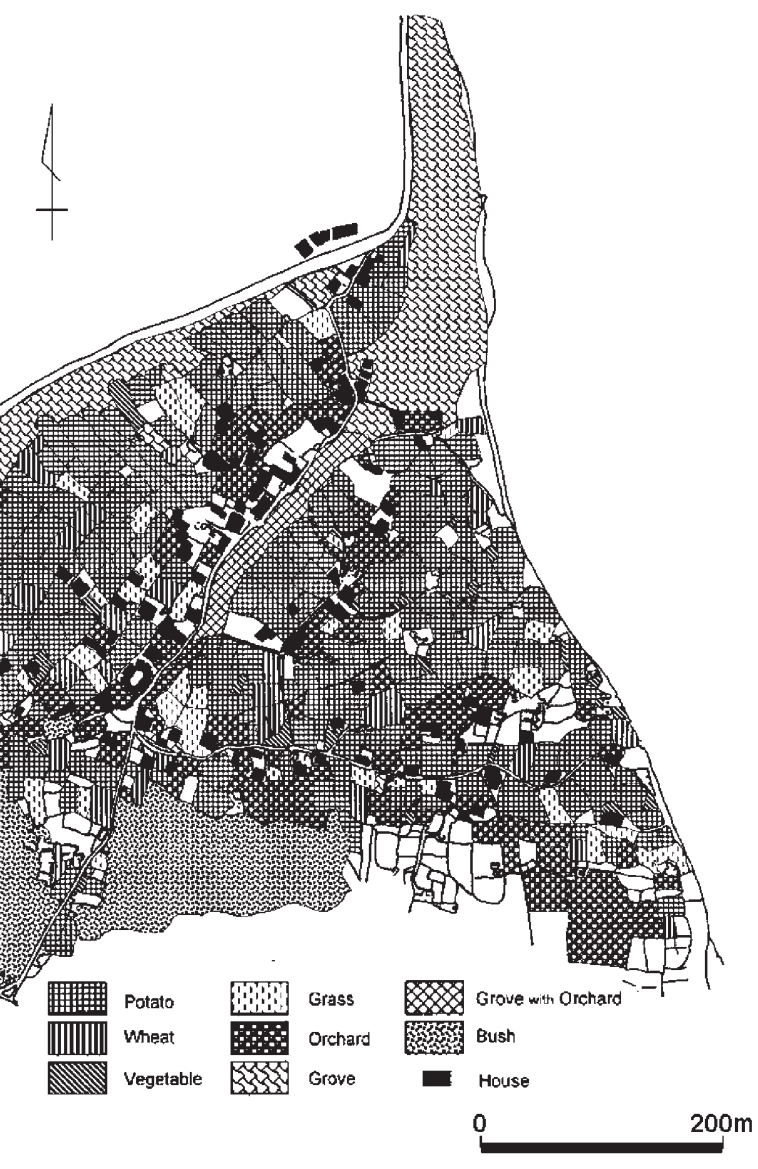

Fig. 4. Land use of Passu village in 2007.

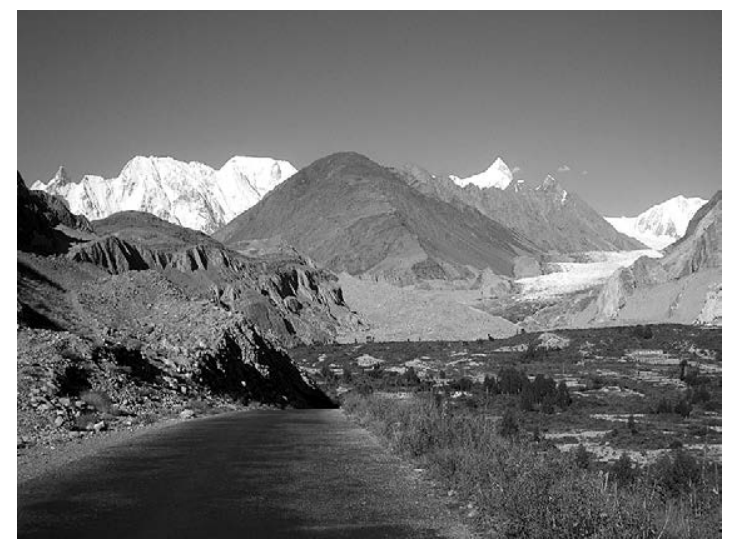

Photo 2. Karakoram Highway and peaks around Passu (Photo: August 2007). has increased, and the citizens have learned how to respond to tourism. As of 2006, Passu village has become the foremost sightseeing destination in Gojal, with seven lodging facilities along with shops and a restaurant (Fig.5) ${ }^{6}$. 


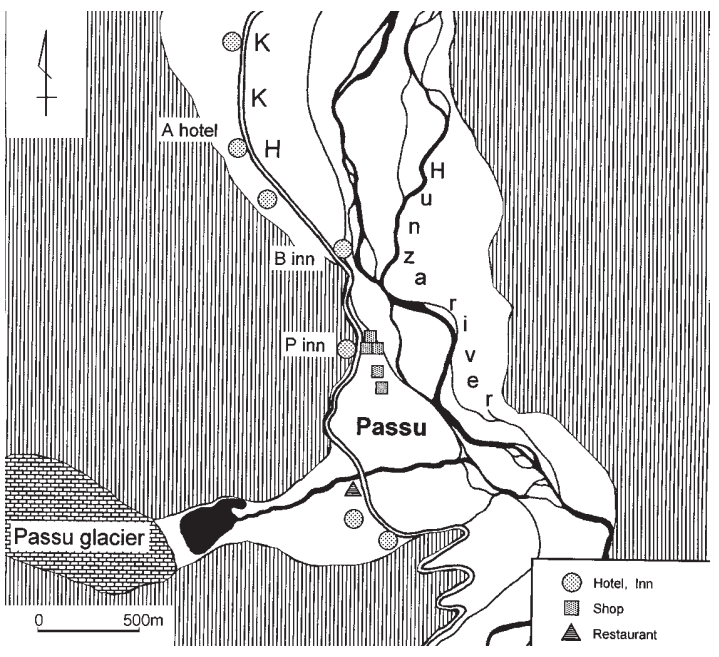

Fig. 5. Location of facilities for tourism in Passu.

\section{Lifestyle changes}

Increased commercial agriculture and the village's continuing transformation into a tourist destination have successfully expanded Passu's economic base, bringing about great change in the citizens' lifestyle as well. Table 1 displays an outline of the family finances in A household. The family, which is composed of a couple in their twenties and three childrenfive individuals in total-owns a plot of farmland which is used almost exclusively for the cultivation of potatoes. In 2005, A family obtained an income of Rs 30,000 through potato sales. The plot of farmland also contains a pasture which feeds the family's five cows. As previously described, stock farming in Passu village was traditionally accomplished through transhumance, but A family raises its cows solely within the settlement and does not possess livestock which benefits from transhumance, such as sheep or goats. In the rest of the village as well, there has been a downward trend in the maintenance of grazing land ${ }^{7}$. On the other hand, cow breeding has increased within the village, and it is believed that agricultural land consumed mostly by pasture cultivation is increasing, especially within the bounds of newly cultivated plots. Though we must naturally also consider the role of soil fertility, the legumes that traditionally served the same function in crop rotation are being cultivated less than they were before, evincing an obvious change in the methods of land usage.

Other than engaging in agriculture, A family runs a general store in the village which yields an annual income of approximately Rs 40,000, which exceeds the amount obtained from potato sales (Table 1). Moreover, the residents of Passu village sometimes have the opportunity to serve as porters for trekkers and mountain climbers, and it is believed that the members of A family have

Table 1. Outline of family finances in a household.

\begin{tabular}{|c|c|c|}
\hline Members & \multicolumn{2}{|c|}{5 (husband*, wife, 3 children) } \\
\hline \multicolumn{3}{|l|}{ Income } \\
\hline Agriculture & Potato & Rs.30,000 \\
\hline Other position & $\begin{array}{l}\text { Shop owner, } \\
\text { etc. }\end{array}$ & Rs. 40,000 \\
\hline
\end{tabular}

Expenses

\begin{tabular}{l|c}
\hline Foods & $\begin{array}{l}\text { Total } \\
\text { Detal: flour }(1,300 \mathrm{~kg}), \text { rice }(80 \mathrm{~kg}), \text { meat, sugar, salt, cooking oil, tea, etc. }\end{array}$ \\
\hline Furnishings & Rs. 10,000 \\
\hline Lighting and heating expenses & Rs. 4,200 \\
\hline School expenses & Rs. 8,000 \\
\hline Agricultural expenses & Rs. 9,000 \\
\hline
\end{tabular}

*29 years old 
obtained temporary income from such work. The family is not unique in this respect, as many of the residents of Passu village obtain income not only from agriculture, that is, through sales of cash crops, but by using their vehicles to transport tourists, contracting with travel agencies in the city to serve as tour guides for tours of the Northern Areas, and so on ${ }^{8)}$.

However, as lifestyles continue to transform, expenses increase proportionately. For instance, A family, which specializes in cultivating potatoes, is unable to provide its own grain, and thus, purchases $1,300 \mathrm{~kg}$ of flour for staple diet. Additionally, due to the diversification of dietary habits, the family also spends approximately Rs 38,000 on grocery items such as rice, meat, oil and spices. Further, the burden of educational expenses, including DJ school, is heavy, and agricultural expenses add up over time as well. As the family uses electric appliances and propane gas, its fuel and electricity costs are also high. In this way, an increase in income produces lifestyle changes, and since this is connected with an increase in expenses, the people of the village are faced with a pressing need to increase their income. As non-agriculture job opportunities are rare, quite a few residents choose to leave the village individually and become so-called migrant workers.

\section{Problems caused by continued development}

Although traditionally utilized for the cultivation of subsistence crops such as grains and legumes, irrigated agriculture in the village has very rapidly become a means of cultivating cash crops, and this has brought about many problems. Currently, the potato is the cash crop can be considered the specialty of Gojal, and in Passu village as well, there is a high degree of dependence upon potato cultivation. Consequently, planting a field with the same crop each year is becoming the norm, and to compensate for the degradation of soil fertility, chemical fertilizers are widely used. The impact of planting fields with the same crop every year also contributes to the need for farmers to periodically purchase seed potatoes. Although the introduction of farm machinery saves labour, the expenses associated with the use of such machinery have risen. Moreover, as there has been a decrease in the cultivation of the grains which were originally subsistence crops and were utilized as staple foods, it has become necessary to purchase such items in large quantities.

Although the forms of agriculture that were originally practiced in the village were appropriate for the regional environment and placed only a light burden upon it, these have been exchanged for forms of agriculture which have the opposite effect. Further, when we take into account the changes in stock farming practices and the continuing trend toward a reduction in grazing land, it becomes clear that the agricultural practices and the traditional dietary habits which are inseparably linked to these practices are continuing to transform. It is expected that this trend will continue to advance further. The traditional agricultural system is presently on the brink of collapse, and the continued existence of the regional dietary habits based on this system is in danger.

In addition to the dedicated cultivation of potatoes, there is also a strong tendency toward reliance on tourism-related industries in Passu village. However, there are many problems associated with tourism in Gojal, and there is a serious risk of excessive reliance on tourist industries. The influx of tourists in Passu village is concentrated in the summer months, with the peak occurring in July and August (Fig. 6). This is because tourism in the area is centred upon activities such as trekking, which are carried out in the summer months and become difficult to engage in once the severe winter cold sets in. However, this concentration of tourism in the summer months means that the busiest tourist period overlaps with the busiest farming period, and for those tourist industry workers in Passu 
village who take up agriculture as a side business, summer is a season of extremely hard labour.

Most of the individuals who visit and stay in Passu village are overseas tourists, primarily from Japan and Europe (Fig. 7). Consequently, the trends in tourism in the village are strongly swayed by international affairs. An examination of the transition in the number of lodgers at three inns in Passu village since the year 2000 reveals that in 2002, the American terrorist attacks of the previous year and the subsequent war in Afghanistan led to a sudden drop in the number of lodgers at B and $\mathrm{P}$ inns. In 2003, due to the Iraq war and the SARS crisis in China, the number of lodgers did not return to previous levels at either inn. Subsequently, though the number of lodgers did begin to increase, in 2006, it still had not returned to its level in 2000 (Fig. 8).

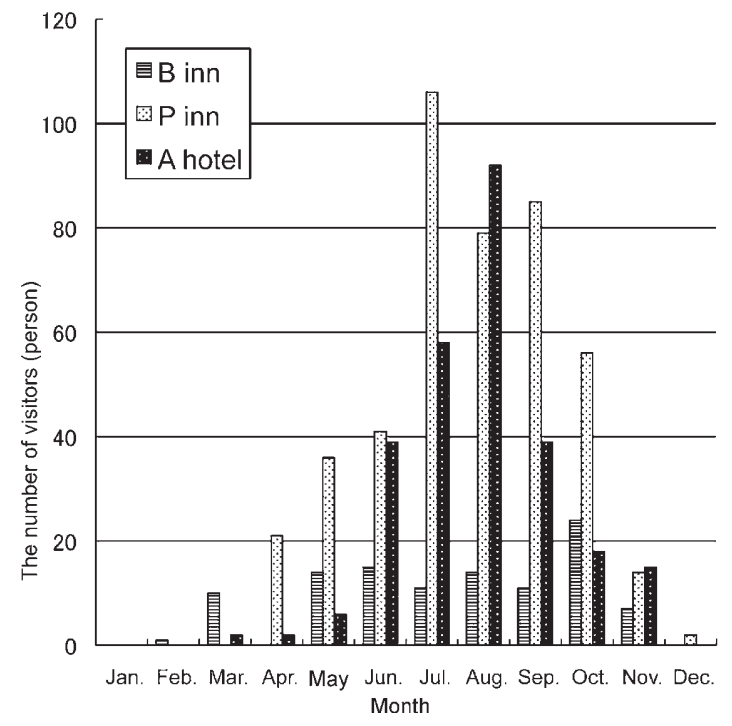

Fig. 6. The monthly number of visitors in three establishments in Passu (2006).

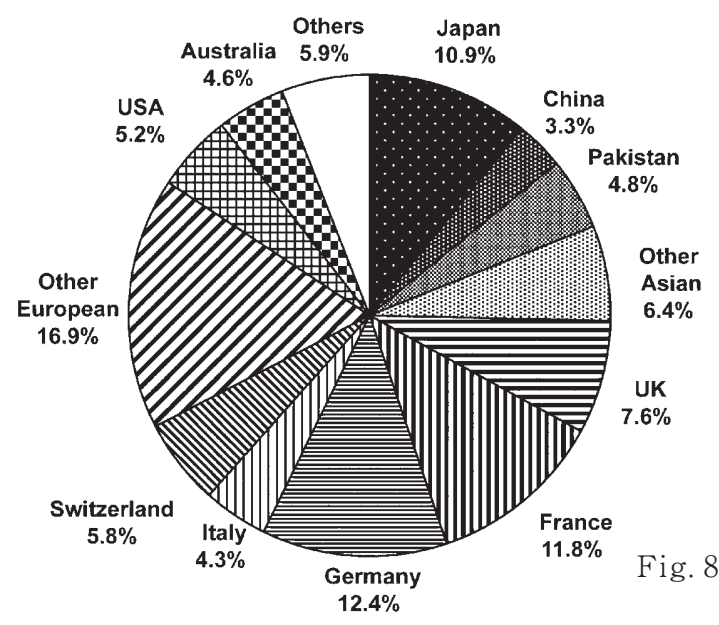

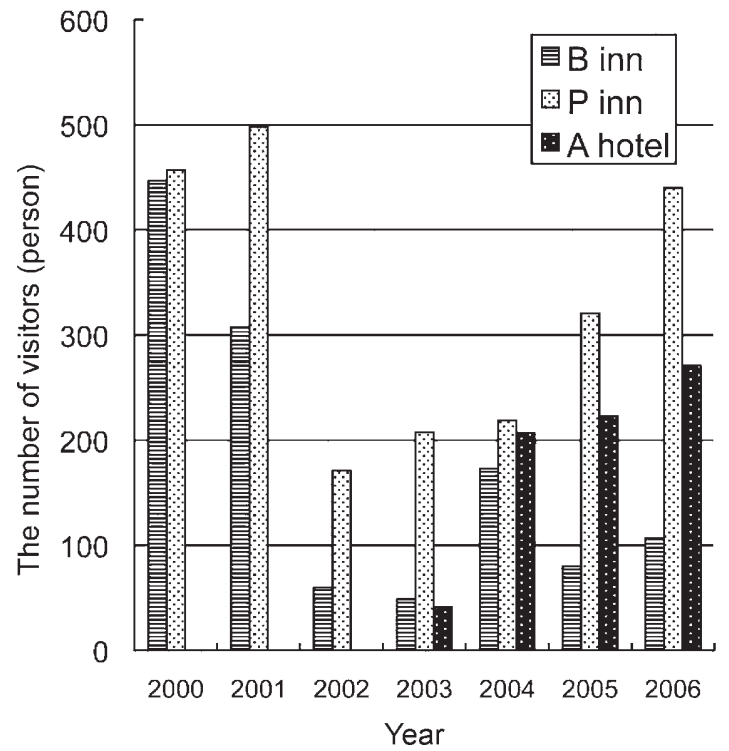

Fig. 7. The annual number of visitors in three establishments in Passu. 
Pakistan is a country which possesses nuclear weapons, and it continues to experience conflicts with India regarding Kashmir. It has deep relations with politically unstable nations such as Afghanistan and the countries of West Asia; therefore, it is often regarded as being subject to certain international risks. This negative image makes foreigners hesitate to visit Pakistan, and this also has the result of making tourism in Gojal sluggish. Under such conditions, the seven lodging facilities represent a somewhat excessive supply, and this could lead to a marked increase in competition between different lodging facilities. Although the number of lodgers at A hotel-a high-grade establishment which opened in 2003 - and at P inn-located near the centre of the village-continue to steadily increase, there is little hope for an increase in the number of lodgers at the low-grade, dilapidated B inn.

\section{Challenges related to advancements in citizen organization and endogenous development in}

\section{Passu village}

To date, the results of the development in Passu village have been a focus on cash crops in agriculture, changes in the methods of raising animals in stock farming, the encouragement of individualized responses to tourism-related industries, a pronounced change in the industrial structure of the village and a complete transformation in lifestyle. Thus far, from the establishment of highways and infrastructure to the participation of the AKF, outside encouragement has played a large role in development of Passu village. In other words, Passu village is favoured by conditions which are highly conducive to developmental progress. There are cases of Wakhi people who, having lived the same lifestyle in a natural environment identical to that of Gojal, have not been encouraged by outside forces to pursue development and have, thus, found their road to growth obstructed (Ochiai, 2008) ${ }^{9)}$.

However, methods of development which entail entrusting the fate of the region to outside encouragement, in fact, create many problems. It has gradually become clear that the present methods of development, which have been seen as the absolutely correct path towards future regional growth, do not necessarily lead to social sustainability in the region. Advanced economic development has brought about an increase in cash income, guiding the people to a materially rich consumer lifestyle; however, changes in lifestyle have led to even greater expenses, and to address this, the people make new demands for economic development. Under such conditions, the traditional occupational system, which did not generate cash income, cannot be looked back upon and deemed inefficient. However, traditional systems such as those of the Wakhi people are, so to speak, precious regional resources which are inextricably linked to the culture of the region, and disregarding them leads to a loss in the regional character which is also important in the promotion of the tourist industry. This development process coincides with the negative trends that have been observed in the regions of relative developmental advancement, and we have arrived at a point in time when it is necessary, so as not to repeat such mistakes, to investigate how to best proceed with development in Passu village and in Gojal.

In order to successfully foster development which makes the best use of regional resources and shows concern for regional sustainability, it is necessary to devise an original method of development which mobilizes the skills of the local people who have a thorough understanding of the region. Moreover, to create the notion of development which is in accord with the collective will of the region, it is absolutely necessary to employ a cooperative structure involving local citizens and to construct (or reconstruct) interregional and interpersonal systems which are mutually complementary. It is also important to organize the citizens of the region. 
In Passu village, there are a number of organizations which have been functioning for some time. For instance, there are the previously described VO and WO, established in 1983 and 1984, respectively, which operate mutually beneficial finance systems using capital to realize various improvements in agriculture-related enterprises. Though the VO and WO were first formed with the support and persistence of the AKRSP, in accordance with the founding aims of these organizations, that is, spurring self-directed development in agriculture and farming villages, they are managed by the villagers who are their core constituents.

The Passu Reform Panel (PRP), established in 1991, is another organization which is managed independently by the village. Currently, the PRP is concerned primarily with the oversight and improvement of stock farming in the village, and it also holds jurisdiction over the management of the grazing land which has been developed along the Batura glacier. As the area along the glacier, including this grazing land, is used as a trekking route by visiting tourists, the PRP also undertakes the management of systems related to trekking tours. The PRP comprehensively manages the usage fees for the porters involved in the tours, the selection and dispatch of porters, the establishment of trekking routes and so on.

Passu village is also host to an organization which was formed to support education, the environment, mediation of disputes, volunteers and the work abilities of women. The Passu Development Organization (PDO) was established as an institution which promotes a form of village development which reflects the plans set forth by these organizations with their varying goals, and which unifies/regulates the ideas of governmental/religious figures. This eight-member organization, established in 1999, is composed of a chairman and a vice chairman who are elected in a village conference as well as six individuals who represent the six family groups ${ }^{10)}$ in the village. Presently, its primary tasks are to raise capital to support development through negotiations with governments and NGOs and to manage this capital. To date, the organization has engaged in such enterprises as the provision of needed resources based on capital provided by individual contributions from Japan and Germany as well as by Japanese NGOs, the Japanese Embassy and the government of Pakistan; the construction of Hunza River levee protection works and new waterworks; and the establishment of irrigation channels on reclaimed land. In other words, the PDO functions as the highest decisionmaking and managing authority when village-related development projects are executed. There is great significance in the fact that village development is carried out with a common goal and according to a fixed plan.

As revealed by the enterprises in which the PDO has been engaged, it is of course the case that Passu village currently requires 'hard' development such as the establishment of infrastructure. To this end, it still relies upon the support of capital raised from outside sources. However, it is important for the village to make decisions with respect to the nature and process of development on its own, considering necessity and usefulness rather than demands and proposals made by outside forces. Thus, it is significant that the PDO functions as an organization which works toward this aim.

Simultaneously, citizens are demanding further economic growth, and in Passu village, which has taken charge of one portion of its distribution economy of widening scale, it is impossible to close off the path to such growth. For this precise reason, it is necessary to search for a method of development which harmonizes economic growth with regional stability, and the society of the region must resist engaging in unrestrained reckless development in the absence of this concept. The PDO is relied upon as an organization whose function is to investigate such methods of development, that 
is, the 'soft' facets of development. For instance, it is important to construct systems to coordinate economic activity which is presently directed by the will of individuals, namely, tourist lodging facilities, transportation businesses, store operation and the cultivation of cash crops in the agriculture industry. Furthermore, we must consider methods of spurring the maturation of new production activity derived from such pursuits, and we must find ways of putting this to use in the economic development of the village while continuing to support the transmission of traditional arts and culture.

\section{Conclusion}

Passu village is favoured by its outstanding natural landscapes and lies along the KKH, and due to such superior conditions, since the late 1980s, there has been marked progress in the increased distribution of goods and the influx of tourists. In addition, entities such as NGOs have aided in the establishment of infrastructure, and the villagers have actively taken charge in such areas as the commercialization of agriculture and the transformation of the area into a tourist destination. As a result, the economic base of the village is maturing, and the lifestyle of the citizens is undergoing dramatic change. However, there are many negative aspects to agricultural practices which specialize only in the single cash crop of potatoes, and great risks accompany excessive reliance on the tourist industry, which is unstable in many ways. Furthermore, for the people, the transition from the traditional subsistence lifestyle to a consumer lifestyle demands further increases in cash income, leading to the creation of a migrant labour movement and separation from the village. If this situation continues to progress, there will be no way to avoid the collapse of the regional society and the loss of the traditional culture, which is a precious regional resource.

In the villages of Gojal, including Passu, which have embraced development and welcomed change, there is a strong demand for the concrete establishment of organizations like the PDO. It is necessary, even while attending to the balance between economic growth and sustainability in the village and paying heed to the individual requests of the citizens, to promote development based on a unified perspective. It is also necessary for individual citizens to comprehend the roles which they can and should play to achieve suitable growth and to proceed with the creation of a system which promotes the division of labour. Further, attention should be paid to the construction of mutually complementary systems which make the best possible use of individual characteristics through cooperation with other villages in Gojal. Fortunately, Gojal has superb human resources which have been cultivated by high educational standards. These individuals have not yet been blessed with the opportunity to fully display their talents, but the desire for growth in the village is strong, and if their powers can be combined, regional organization and sustainable development will likely be realized.

\section{Notes}

1 ) Surveyed by Committee Ismaili council for Gojal Bala in 2005.

2) According to SP's office in Gilgit, the number of foreign visitors to Gilgit increased from 4,500 in 1985 to 9,253 in 1986 , and it is believed that the number of foreign visitors to Gojal increased as well.

3 ) In commemoration of the $60^{\text {th }}$ anniversary (diamond jubilee) of the ascension of the previous imam, Aga Khan III (who reigned from 1895 to 1957), DJ schools were constructed in a number of areas.

4 ) Surveyed by Committee Ismaili council for Gulmit in 2006.

5) The $7,000 \mathrm{~m}$ peaks which may be viewed from the area near the village include Batura (7,785 $\mathrm{m})$, Shispare $(7,611 \mathrm{~m})$ and Passu $(7,478 \mathrm{~m})$. Furthermore, to the northeast of the village on the opposite bank of the Hunza River rises Tupopdan $(6,106 \mathrm{~m})$, which has eroded in a unique saw-tooth pattern and serves as a symbol for the area. 
6 ) In Gojal, Sost, where the Chinese border immigration office is located, boasts the largest number of tourism-related facilities after Gulmit, the regional tourist centre.

7 ) According to the village (DJ school) survey in 2006, the livestock of all households in Passu village totaled 207 yaks, 348 cows, 490 sheep and 1,444 goats.

8 ) According to the 2006 (DJ school) village survey, although all 112 households were engaged in agriculture, only 36 households specialized in agricultural work. The other households were involved in non-agricultural work, including tourismrelated jobs and cases where the head of the household worked in the city or abroad.

9 ) Ishkoman, which lies in the northwest of the Northern Areas of Pakistan, is an area which resembles Gojal in that the Wakhi reside there; however, these Wakhi people live away from the highway, and outside visitors including tourists, are rare. As the contributions of NGOs to the area are minimal and the establishment of infrastructure remains insufficient, the area exhibits a marked disparity with Gojal in terms of economic growth.

10) The six family groups in Passu village are Sakhi, Magni, Alvi, Dinali, Wizeer and Mir.

\section{References}

AKRSP [Aga Khan Rural Support Programme] (1998): Fifteenth Annual Review. Aga Khan Rural Support Programme.

Hiroshima, M. (1987): Kashmir to Hoppou-chiiki (Kashmir and Northern Areas). In Konishi, M.(ed.) Motto shiritai Pakistan (Detailed Introduction on Pakistan). Koubunndo. [in Japanese]

Kreutzmann, H. (1993): Challenge and response in the Karakoram: Socioeconomic transformation in Hunza, Northern Areas, Pakistan. Mountain Research and Development, 13, 19-39.

Mizushima, K. (1990): Agriculture of Pakistan's North Area: A case of Shimshal. The Chiri Shiso (Annals of the Geography), 31-2, 54-61. [in Japanese]

Mizushima, K. (2006): NGO organization of the Wakhi people in Gojal, Northern Area of Pakistan: In case study of Hussaini village. Proceedings of The Institute of Natural Sciences Nihon University, 41, 31-38. [in Japanese]

Mizushima, K. (2008): Irrigation system in Gojal, Northern Area of Pakistan: In case study of Hussaini village. Proceedings of The Institute of Natural Sciences Nihon University, 43, 43-53. [in Japanese]

Namai, S. (1982): Karakoram kikou(1) Pakistan no Nouson kara (A travel note on a farm village in Karakoram Range, Pakistan). Chiri (Geography), 27 (1), 81-86. [in Japanese]

Nejima, S. (2002): Islam to Kaihatsu: Karakoram ni okeru Ismail ha no henyou (Changes according to the developments on Ismaili people in Karakoram Mountains). Nakanishiyashuppan. [in Japanese]

Ochiai, Y. (1999): The inhabitant's life style of Passu village in the Northern Areas of Pakistan. The Chiri Shiso (Annals of the Geography), 40 (2), 52-64. [in Japanese]

Ochiai, Y. (2000): Tourism development and change on situation of Gojal area in the Northern Areas of Pakistan. The Chiri Shiso (Annals of the Geography), 41 (1 and 2), 31-43. [in Japanese]

Ochiai, Y. (2001): Ecotourism potential of Gojal area in the Northern Areas of Pakistan. Annals of the Geography (The Chiri Shiso), 42 (2), 27-38. [in Japanese]

Ochiai, Y. (2003): Change on the life style in Passu village, the Northern Areas of Pakistan: Inhabitants' participation in regional development and tourism. Proceedings of The Institute of Natural Sciences Nihon University, 38, 19-27. [in Japanese]

Ochiai, Y. (2008): The regional differences in lifestyle on villagers of Wakhi living around the Pamir. Proceedings of The Institute of Natural Sciences Nihon University, 43, 55-65. [in Japanese]

Ochiai, Y. and Mizushima, K. (2004): Changes in life styles as a result of regional development in Gojal, Northern Areas of Pakistan. Chigaku Zasshi (Journal of Geography), 113, 312-329. [in Japanese]

Sakai, Y. (1989): Shimshal mura no shizen to seikatsu (Nature and lifestyle in Shimshal village). Chiri (Geogaphy), 34 (7), 115-118. [in Japanese]

Waragai, T. (1995): Landform classification using multispectral analysis based on LANDSAT MSS data from the Hunza Valley, Northwestern Karakoram Mountains, Pakistan. Proceedings of The Institute of Natural Sciences Nihon University, 30, 23-36. (in Japanese)

Waragai, T. (1996): A one-year observation of boulder surface temperature in the Hunza Valley, Northwestern Karakoram mountains, Pakistan. Proceedings of The Institute of Natural Sciences Nihon University, 31, 69-80. [in Japanese] 
Waragai, T. (1997): Diurnal temperature changes of rock surface and air in the Hunza Valley, Karakoram Mountains. The Chiri Shiso (Annals of the Geography), 38 (2), 62-70. [in Japanese]

Waragai, T. (1999): Weathering processes in rock surface in the Hunza Valley, Karakoram, North Pakistan. $Z$. Geomorph. N.F., Suppl. -Bd., 119, 119-136.

Waragai, T. (2001): Laminated layers and formation of calcretes on the lateral moraine near the Batura Glacier, Northern Pakistan. The Chiri Shiso (Annals of the Geography), 42 (2), 1-9. [in Japanese]

Waragai, T. (2008): Physiographical features in upper Hunza region, Karakoram, Northern Pakistan: Preliminary data. Proceedings of The Institute of Natural Sciences Nihon University 2008, 67-75. [in Japanese]

Weeks, Richard V. (ed.) (1984): Muslim Peoples: a World Ethnographic Survey.2nd ed. Greenwood Press. 2vols.

Yamauchi, H. (1989): The progress of exchange and research program in 1988 by Nihon University in Shimshal village. Chiri (Geography), 34 (6), 88-92. [in Japanese] 